\title{
Obituaries
}

\section{RICHARD B. BRANDT}

Richard B. Brandt died on 10 September 1997 in Ann Arbor, Michigan. He was born in Ohio in 1910. Brandt earned BAs from Denison College and Cambridge University, and a PhD from Yale in 1936. He taught at Swarthmore College from 1937-64, and at University of Michigan from 1964-81. His former Swarthmore students include David Lewis, Gilbert Harman, Stephen Nathanson, Peter Unger, and Allan Gibbard. Among his former Michigan students were Michael Davis, Gregory Kavka, Mark Overvold, Warren Quinn, Holly Goldman, and Gregory Trianosky. Although he published widely in philosophy, he was best known for his work in moral philosophy. Indeed, after he joined William Frankena and C. L. Stevenson at Michigan in the 1960s, that University was widely thought to have the strongest team of moral philosophers in America.

Brandt will be remembered for his development of rule-utilitarianism. He first defended the theory (as well as coined its name) in his textbook Ethical Theory (Englewood Cliffs, NJ, 1959). In the 1960s, he published a series of articles in which he refined the theory and replied to critics. These essays were widely discussed and reprinted, and eventually collected together in Brandt's Morality, Utilitarianism, and Rights (Cambridge, 1992). He gave the John Locke Lectures in Oxford in 1974, and these were published as A Theory of the Good and the Right (Oxford, 1979), probably his most important book. The year before his death, he published further reflections on the areas of ethics to which he had long contributed: Facts, Values, and Morality (Cambridge, 1996). A Festschrift for Frankena, Stevenson, and Brandt was published in 1978 (Values and Morals, edited by Alvin Goldman and Jaegwon Kim, Dordrecht). A collection of new essays on Brandt appeared in 1993 (Rationality, Rules, and Utility: New Essays on the Moral Philosophy of Richard B. Brandt, edited by Brad Hooker, Boulder). Brandt served on the Board of Utilitas for a number of years.

No adequate history of utilitarian philosophy could be written which did not discuss Brandt's development of rule-utilitarianism. While J. O. Urmson is rightly credited as the first twentieth-century ethicist to have focused on this moral theory, Brandt and the Nobel Prize winning economist John Harsanyi have been its most prominent champions. But here is not the place to revisit the advantages and disadvantages of this version of utilitarianism. See Andrew Moore's excellent 'The Utilitarian Ethics of R. B. Brandt', Utilitas, v (1993).

BRAD HOOKER 